\title{
OPTIMIZATION OF NUTRIENT COMPOSITION MEDIUM AND CULTURE CONDITION FOR MANNANASE PRODUCTION BY BACILLUS VELEZENSIS NRC-1 USING TAGUCHI METHOD
}

\author{
Tarek E. Mazeed ${ }^{a}$, Tamer Atef ${ }^{\mathrm{a}}$, Ahmed A. El-Beih ${ }^{\mathrm{a}}$, Bakry M. Haroon ${ }^{\mathrm{b}}$ and Ahmed I. El- \\ Diwany $^{\text {a }}$ \\ ${ }^{a}$ Chemistry of Natural and Microbial Products Department, National Research Centre, \\ Dokki, Giza 12622, Egypt. \\ ${ }^{\mathrm{b}}$ Botany and Microbiology Department, Faculty of Science (Boys), Al-Azhar University.
}

\begin{abstract}
The effect of different nutrient composition media on the production of mannanase by Bacillus velezensis NRC-1 was investigated. Medium 1 (composed of $(\mathrm{g} / \mathrm{L})$, peptone, 2.0; $\left(\mathrm{NH}_{4}\right)_{2} \mathrm{SO}_{4}, 1.5 ; \mathrm{MgSO}_{4} \cdot 7 \mathrm{H}_{2} \mathrm{O}, 0.5 ; \mathrm{K}_{2} \mathrm{HPO}_{4}, 10.0$; locust bean gum, 10.0, urea and $0.3, \mathrm{pH}$ 5.3) was found to be the most favorable medium for mannanase production which recorded, $2.19 \mathrm{U} / \mathrm{mL}$, after 7 days of incubation at $30^{\circ} \mathrm{C}$. Taguchi orthogonal array method was used for optimization of nutrient composition medium and culture condition for mannanase production. Eight nutrient factors were studied including peptone, ammonium sulphate, urea, magnesium sulphate, dihydrogen potassium phosphate, locust bean gum, $\mathrm{pH}$ and fermentation volume with three levels. Analysis of variance (ANOVA) revealed that peptone concentration, locust bean gum and $\mathrm{pH}$ of the medium were the most influencing factors with percent participation 19.25, 13.46 and 57.89\%, respectively. An increase in mannanase production to $8.7 \mathrm{U} / \mathrm{mL}$ could be achived after the optimization process.
\end{abstract}

Keywords: Bacillus velezensis, Taguchi method, Mannanase

\section{INTRODUCTION}

Endo- $\beta$-1,4-mannanase (EC 3.2.1.78) is a crucial enzyme for the depolymerization of unsubstituted mannans, galactomannans and galacto-glucomannans (Stalbrand et al., 1993; de Vries and Visser, 2001). The mannanases are widely used in food, instant coffee processing, paper and pulp industries (Wong and Saddler, 1993; Montiel et al., 1999; Sachslehner et al., 2000; Ferreira and Filho, 2004; Gübitz et al., 1997). Recently $\beta-1,4-$ mannanases have been shown to be effective in laundry detergents (McCoy, 2001 and Schäfer et al., 2002). Mannanase is also used in poultry feed industry to break down the mannan found in poultry feeds to oligosaccharides and reduce intestinal viscosity which then improves feed efficiency and increase poultry growth (lee et al., 2003 and Wu et al., 2005).

Mannanases are produced from bacteria as Bacillus subtilis (Mendoza et al., 1995), Streptomyces lividans (Arcand et al., 1993) and Vibrio species (Tamaru et al., 1995); fungi as Aspergillus species, Trichoderma reesei (Stalbrand et al., 1995), Penicillium occitanis and plants as lycopersicon esculentum (Bewley et al., 1997).

The Taguchi method has been recently used for the optimization of production of many enzymes as xylanses (Azin $\boldsymbol{e t}$ al., 2007) and laccases (Prasad $\boldsymbol{e t}$ al., 2005)

In this study, the effect of some medium composition, $\mathrm{pH}$ and fermentation volume on mannanase biosynthesis by Bacillus velezensis NRC-1 using Taguchi method was conducted. 


\section{MATERIALS AND METHODS}

\subsection{Microorganism}

The microorganism used in this study, Bacillus velezensis NRC-1 was isolated locally from dehaired skin of sheep. The identification of Bacillus velezensis NRC-1 was carried out using partial sequencing of ribosomal DNA gene, with phylogenetic analysis.

\subsection{Chemicals}

All chemicals were of pure grade produced by known manufacturers.

\subsection{Culture media}

The medium used for inoculating and maintenance of $B$. velezensis NRC-1 composed of $(\mathrm{g} / \mathrm{L})$ peptone, 5; beef extract, 3.0; $\mathrm{NaCl}, 8.0$ and agar 12.0. For growth enhancement tryptone liquid nutrient medium was used $(\mathrm{g} / \mathrm{L})$ tryptone, 10.0 ; yeast extract, 5.0 and $\mathrm{NaCl}$, 10.0 .

\subsection{Production media}

Different types of nutrient production media of various compositions were used to select the most suitable medium for the production of mannanase. The types of media and composition are listed below. Ingredients of each medium were dissolved in $1 \mathrm{~L}$ of distilled water. The prepared nutrient medium was distributed in $100 \mathrm{~mL}$ portions in triplicate, each transferred into $250 \mathrm{~mL}$ conical flasks plugged with cotton and sterilized by autoclaving at $121{ }^{\circ} \mathrm{C}$ and $1.5 \mathrm{~atm}$ for $20 \mathrm{~min}$. Some components of the nutrient media such as sugar were sterilized separately and then added aseptically to the media.

Medium 1. (g/L), peptone, 2.0; $\left(\mathrm{NH}_{4}\right)_{2} \mathrm{SO}_{4}, 1.5 ; \mathrm{MgSO}_{4} \cdot 7 \mathrm{H}_{2} \mathrm{O}, 0.5 ; \mathrm{K}_{2} \mathrm{HPO}_{4}, 10.0$; locust bean gum, 10.0; urea 0.3, and the $\mathrm{pH}$ was adjusted to 5.3 (Arisan-Atac et al., 1993).

Medium 2. (g/100ml) (mannose submerged fermentation)

Locust bean gum, 0.5; $\mathrm{Na}_{2} \mathrm{HPO}_{4}, 0.7 ; \mathrm{K}_{2} \mathrm{HPO}_{4}, 3.0 ; \mathrm{NH}_{4} \mathrm{Cl}, 0.1 ; \mathrm{NaCl}, 0.05$ and the pH was adjusted at 8 (Bhoria et al., 2009).

Medium 3. $(\mathrm{g} / \mathrm{L})$

Guar gum, 5.0; $\mathrm{Na}_{2} \mathrm{HPO}_{4}, 7.0 ; \mathrm{KH}_{2} \mathrm{PO}_{4}, 3.0 ; \mathrm{NH}_{4} \mathrm{Cl}, 1.0 ; \mathrm{NaCl}, 0.5$ and the $\mathrm{pH}$ was adjusted at 8 (Bhoria et al., 2009).

Medium 4. $(\mathrm{g} / \mathrm{L})$

Glycerol, 20.0; meat peptone, 20.0; $\mathrm{KH}_{2} \mathrm{PO}_{4}, 1.2 ; \mathrm{MgSO}_{4} .7 \mathrm{H}_{2} \mathrm{O}, 1.5 ; \mathrm{KCl}, 0.6$; $\mathrm{NH}_{4} \mathrm{NO}_{2}, 0.5$ and traces of metal solution in a level $0.3 \mathrm{ml} / \mathrm{L}$ (Sachslehner et al., 1998).

Medium 5. (\%)

Konjac powder, 1.0; Yeast extract, 2.0; Polypeptone, 2.0; $\mathrm{KH}_{2} \mathrm{PO}_{4}, \quad 0.1$; $\mathrm{MgSO}_{4} .7 \mathrm{H}_{2} \mathrm{O}, 0.02$ and $\mathrm{NaCO}_{3} 0.5$ (Akino et al., 1987).

Medium 6. $(\mathrm{g} / 100 \mathrm{ml})$

Locust bean gum, 1.0; Polypeptone, 3.0; $\mathrm{MgSO}_{4} .7 \mathrm{H}_{2} \mathrm{O}, 0.06 ; \mathrm{KH}_{2} \mathrm{PO}_{4}$, 1.5; Corn steep liquor, 2.5 and the $\mathrm{pH}$ was adjusted at 7 (Abe et al., 1994).

Medium 7. (g/100ml)

Konjac powder, 2.0; $\mathrm{Na}_{2} \mathrm{HPO}_{4}, 0.5 ; \mathrm{MgSO}_{4} .7 \mathrm{H}_{2} \mathrm{O}, 0.6$; beef peptone, 0.8 and yeast extract 0.4 (Jiang et al., 2006). 
Medium 8. (g/L)

Konjac powder, 6.0; meat peptone, 6.0; corn steep liquor, 1.0; $\left(\mathrm{NH}_{4}\right)_{2} \mathrm{SO}_{4}, 1.0$; $\mathrm{Na}_{2} \mathrm{HPO}_{4}, 0.8 ; \mathrm{K} \mathrm{H}_{2} \mathrm{PO}_{4}, 0.06 ; \mathrm{MgCl}_{2}, 0.12 ; \mathrm{CaCl}_{2}, 0.6 ; \mathrm{FeSO}_{4}, 0.002$ and $\mathrm{Na}_{2} \mathrm{CO}_{3}, 0.6$ (Feng et al., 2003).

Medium 9. $(\mathrm{g} / \mathrm{L})$

Starch insoluble, 6.0; $\mathrm{Na}_{2} \mathrm{HPO}_{4}, 7.0 ; \mathrm{KH}_{2} \mathrm{PO}_{4}, 3.0 ; \mathrm{NH}_{4} \mathrm{Cl}_{2}, 1.0 ; \mathrm{NaCl}, 0.5$ and the $\mathrm{pH}$ was adjusted at 8 (Bhoria et al., 2009).

\subsection{Enzyme assay :}

The culture extract of the fermentation medium was centrifuged at $10,000 \times \mathrm{g}$ for 15 min. The supernatant was used as the source of enzymes. Mannanase activity was determined by measuring total reducing sugars released from $1 \%(\mathrm{w} / \mathrm{v})$ locust bean gum as a substrate in $1 \mathrm{~mL}$ citrate buffer, $50 \mathrm{mM}$, pH 5, using $0.5 \mathrm{~mL}$ of the growth broth containing mannanase enzyme was added. The mixture was incubated at $50{ }^{\circ} \mathrm{C}$ for $10 \mathrm{~min}$ and the enzyme activity was determined by the method of Somogyi (Somogyi, 1945). One unit of $\beta$ mannanase activity was defined as the amount of enzyme which releases 1 mol of reducing sugar as equivalent to D-mannose per minute under the above mentioned conditions.

2.6. Protein determination :

The concentration of soluble proteins was estimated according to the method of Lowry et al., (1951) using bovine serum albumin (BSA) as the standard reference.

\section{EXPERIMENTAL DESIGN AND STATISTICAL ANALYSIS:}

Taguchi method was used for optimization of medium composition and culture conditions to produce mannanase enzyme. Standard orthogonal array L-27 $\left(3^{8}\right)$ was selected to examine eight-factors (peptone, ammonium sulphate, urea, magnesium sulphate, dihydrogen potassium phosphate, locust bean gum, $\mathrm{pH}$ and volume) with three levels. The factors were selected on basis of standard fermentation conditions on medium No.1, with changes in some physical conditions as $\mathrm{pH}$ and volume, to measure their effect on mannanase biosynthesis from $B$. velezensis NRC-1. The symbolic array L-27 of experimental matrix represents the size of experiment and the number of runs (i.e. 27 experimental trails) with layout $\left(3^{8}\right)$. The three levels of the eight factors were coded as 1,2 and 3 (Table 1). The total degree of freedom (DOF) for OA L-27 set was 26 (number of runs minus one). In the design OA, each column consisted of a number of conditions depending on the levels assigned to each factor. The runs involved a particular combination of levels to which the factors were set, and the diversity of factors was studied by crossing the factors. The whole experiment was performed in triplicate manner. An analysis of variance (ANOVA) for the obtained results was investigated. The incubation of culture medium was carried out at $30^{\circ} \mathrm{C}$ for 7 days in all Taguchi runs. 
Table 1. Selected fermentation factors and their assigned levels for optimization process for B. velezensis.

\begin{tabular}{|l|l|c|c|c|}
\hline Serial no. & Factor & Level 1 & Level 2 & Level 3 \\
\hline 1 & Peptone (g/L) & 3.5 & 2.0 & 0.5 \\
\hline 2 & Ammonium sulphate $(\mathrm{g} / \mathrm{L})$ & 1.5 & 1.0 & 0.2 \\
\hline 3 & Urea $(\mathrm{g} / \mathrm{L})$ & 0.30 & 0.10 & 0.05 \\
\hline 4 & Magnesium sulphate $(\mathrm{g} / \mathrm{L})$ & 0.50 & 0.20 & 0.05 \\
\hline 5 & Potassium dihydrogen phosphate $(\mathrm{g} / \mathrm{L})$ & 15 & 10 & 5 \\
\hline 6 & Locust bean gum $(\mathrm{g} / \mathrm{L})$ & 15 & 10 & 5 \\
\hline 7 & Volume $(\mathrm{mL})$ & 50 & 25 & 15 \\
\hline 8 & $\mathrm{pH}$ & 8.0 & 6.5 & 5.3 \\
\hline
\end{tabular}

\section{RESULTS}

A preliminary experiment was conducted to select the most suitable nutrient medium for mannanase biosynthesis by $B$. velezensis. Nine nutrient media with varying compositions were selected from previous studies carried out on mannanase biosynthesis with different incubation periods (3, 5 and 7 days). Medium 1 was found to be the most suitable medium with mannanase biosynthesis of $2.19 \mathrm{U} / \mathrm{mL}$ after 7 days incubation (Table 2). 
Table 2. Effect of different culture nutrient media during different incubation periods on the biosynthesis of mannanase by Bacillus velezensis NRC-1.

\begin{tabular}{|c|c|c|c|c|c|c|}
\hline $\begin{array}{c}\text { Media } \\
\text { No. }\end{array}$ & $\begin{array}{c}\text { Incubation } \\
\text { period } \\
\text { (days) }\end{array}$ & $\begin{array}{l}\text { Dry weight } \\
\text { of cells } \\
(\mathrm{g})\end{array}$ & $\mathrm{pH}$ & $\begin{array}{l}\text { Protein } \\
\text { content } \\
(\mathrm{mg} / \mathrm{mL})\end{array}$ & $\begin{array}{c}\text { Mannanase } \\
\text { activity } \\
\text { (U/mL) }\end{array}$ & $\begin{array}{l}\text { Specific } \\
\text { activity } \\
\text { (U.mg }^{-1} \\
\text { protein) }\end{array}$ \\
\hline \multirow{3}{*}{1} & 3 & 0.50 & 6.5 & 1.80 & 1.20 & 0.67 \\
\hline & 5 & 0.54 & 6.0 & 2.56 & 1.55 & 0.61 \\
\hline & 7 & 0.73 & 6.5 & 2.09 & 2.19 & 1.05 \\
\hline \multirow{3}{*}{2} & 3 & 1.20 & 6.0 & 1.06 & 0.85 & 0.80 \\
\hline & 5 & 1.13 & 5.5 & 1.46 & 1.23 & 0.84 \\
\hline & 7 & 1.98 & 6.0 & 1.5 & 1.57 & 1.05 \\
\hline \multirow{3}{*}{3} & 3 & 0.7 & 8.0 & 0.73 & 0.10 & 0.13 \\
\hline & 5 & 0.64 & 7.0 & 1.38 & 0.14 & 0.10 \\
\hline & 7 & 0.85 & 7.5 & 1.81 & 0.13 & 0.07 \\
\hline \multirow{3}{*}{4} & 3 & 2.4 & 5.5 & 3.92 & 0.10 & 0.02 \\
\hline & 5 & 2.32 & 7.5 & 6.53 & 0.13 & 0.02 \\
\hline & 7 & 1.89 & 8.5 & 6.16 & - & - \\
\hline \multirow{3}{*}{5} & 3 & 3.0 & 9.0 & 4.29 & 2.12 & 0.49 \\
\hline & 5 & 2.89 & 9.0 & 10.5 & 2.11 & 0.20 \\
\hline & 7 & 2.81 & 9.0 & 11.3 & 1.54 & 0.14 \\
\hline \multirow{3}{*}{6} & 3 & 2.4 & 7.0 & 3.84 & 1.44 & 0.38 \\
\hline & 5 & 2.23 & 8.0 & 8.25 & 1.95 & 0.24 \\
\hline & 7 & 1.04 & 8.5 & 9.04 & 1.76 & 0.19 \\
\hline \multirow{3}{*}{7} & 3 & 1.12 & 8.0 & 2.33 & 1.64 & 0.70 \\
\hline & 5 & 1.07 & 7.5 & 4.11 & 1.93 & 0.47 \\
\hline & 7 & 0.60 & 7.5 & 4.04 & 2.06 & 0.63 \\
\hline \multirow{3}{*}{8} & 3 & 0.63 & 8.5 & 1.74 & 1.23 & 0.71 \\
\hline & 5 & 0.61 & 7.0 & 2.13 & 1.29 & 0.61 \\
\hline & 7 & 0.72 & 8.5 & 2.02 & 1.95 & 0.97 \\
\hline \multirow{3}{*}{9} & 3 & 0.90 & 7.0 & 1.03 & 0.16 & 0.16 \\
\hline & 5 & 0.85 & 6.0 & 1.24 & 0.21 & 0.17 \\
\hline & 7 & 0.84 & 7.0 & 1.22 & 0.35 & 0.29 \\
\hline
\end{tabular}


As a result medium 1 was selected for optimization process using Taguchi method. By using Taguchi method standard orthogonal array L-27 $\left(3^{8}\right)$ eight-factors (peptone, ammonium sulphate, urea, magnesium sulphate, dihydrogen potassium phosphate, locust bean gum, $\mathrm{pH}$ and volume) with three levels from each was selected to study their effect on mannanase production (Table 3). The results of the experiments performed revealed that the maximum production of mannanase was $7.95 \mathrm{U} / \mathrm{mL}$ under the following medium composition $(\mathrm{g} / \mathrm{L})$ peptone, 3.5; ammonium sulphate, 1.50; urea, 0.30; magnesium sulphate, 0.20 ; potassium dihydrogen phosphate, 10.0; locust bean gum, 10.0 with fermentation volume, $25 \mathrm{~mL}$ and $\mathrm{pH}$ 6.5. Analysis of variance (ANOVA) of the obtained results (Table 4) revealed that changing of peptone and locust bean gum in medium composition together with $\mathrm{pH}$ have been the most important factors in causing differences in the obtained results.

When these results were analyzed, an optimum condition could be attained by calculations as follows, medium composition $(\mathrm{g} / \mathrm{L})$ peptone, 3.5 ; ammonium sulphate, 1.50; urea, 0.30; magnesium sulphate, 0.05 ; potassium dihydrogen phosphate, 12.0 ; locust bean gum, 15.0 with fermentation volume, $25 \mathrm{~mL}$ and $\mathrm{pH}$ 6.5. Under these conditions, mannanase biosynthesis was expected to be $8.9 \mathrm{U} / \mathrm{mL}$. However, after performing the experiment with the above mentioned conditions, the produced mannanse was found to be $8.7 \mathrm{U} / \mathrm{mL}$. Since the difference between the expected and actual is $2.25 \%$, the result was regarded as acceptable. 
Table 3. Taguchi method orthogonal array L-27 $\left(3^{8}\right)$ of designed experiments.

\begin{tabular}{|c|c|c|c|c|c|c|c|c|c|c|}
\hline \multirow{2}{*}{ Run } & \multicolumn{8}{|c|}{ Factor } & \multirow{2}{*}{$\begin{array}{c}\text { Mannanase activity } \\
(\mathrm{U} / \mathrm{mL})\end{array}$} & \multirow{2}{*}{$\begin{array}{l}\text { D.W. } \\
(\mathrm{g} / \mathrm{L})\end{array}$} \\
\hline & 1 & 2 & 3 & 4 & 5 & 6 & 7 & 8 & & \\
\hline 1 & 2.0 & 1.5 & 0.05 & 0.20 & 5 & 15 & 25 & 5.3 & 1.93 & 0.53 \\
\hline 2 & 0.5 & 0.2 & 0.30 & 0.05 & 15 & 5 & 25 & 5.3 & 2.07 & 0.73 \\
\hline 3 & 0.5 & 1.0 & 0.05 & 0.05 & 5 & 10 & 50 & 8.0 & 6.11 & 0.84 \\
\hline 4 & 0.5 & 0.2 & 0.30 & 0.50 & 10 & 15 & 15 & 8.0 & 4.31 & 0.4 \\
\hline 5 & 3.5 & 0.2 & 0.05 & 0.50 & 5 & 5 & 15 & 6.5 & 6.43 & 0.26 \\
\hline 6 & 2.0 & 1.0 & 0.30 & 0.20 & 15 & 10 & 15 & 6.5 & 7.48 & 0.57 \\
\hline 7 & 2.0 & 0.2 & 0.10 & 0.20 & 10 & 5 & 50 & 8.0 & 3.33 & 0.94 \\
\hline 8 & 0.5 & 1.0 & 0.05 & 0.20 & 10 & 15 & 15 & 5.3 & 3.51 & 0.47 \\
\hline 9 & 2.0 & 1.5 & 0.05 & 0.05 & 15 & 10 & 15 & 8.0 & 5.83 & 0.65 \\
\hline 10 & 3.5 & 0.2 & 0.05 & 0.05 & 10 & 10 & 25 & 8.0 & 4.98 & 0.72 \\
\hline 11 & 3.5 & 1.5 & 0.30 & 0.20 & 10 & 10 & 25 & 6.5 & 7.95 & 0.73 \\
\hline 12 & 2.0 & 0.2 & 0.10 & 0.50 & 15 & 10 & 15 & 5.3 & 4.29 & 0.48 \\
\hline 13 & 2.0 & 0.2 & 0.10 & 0.05 & 5 & 15 & 25 & 6.5 & 6.21 & 0.52 \\
\hline 14 & 3.5 & 1.0 & 0.10 & 0.50 & 10 & 10 & 25 & 5.3 & 4.85 & 0.69 \\
\hline 15 & 2.0 & 1.0 & 0.30 & 0.50 & 5 & 15 & 25 & 8.0 & 6.33 & 0.5 \\
\hline 16 & 2.0 & 1.5 & 0.05 & 0.50 & 10 & 5 & 50 & 6.5 & 3.92 & 0.72 \\
\hline 17 & 3.5 & 1.0 & 0.10 & 0.05 & 15 & 15 & 50 & 6.5 & 7.96 & 1.62 \\
\hline 18 & 0.5 & 1.5 & 0.10 & 0.50 & 5 & 10 & 50 & 5.3 & 1.45 & 0.73 \\
\hline 19 & 3.5 & 1.5 & 0.30 & 0.50 & 15 & 15 & 50 & 8.0 & 6.69 & 1.87 \\
\hline 20 & 3.5 & 0.2 & 0.05 & 0.20 & 15 & 15 & 50 & 5.3 & 3.57 & 1.57 \\
\hline 21 & 0.5 & 1.0 & 0.05 & 0.50 & 15 & 5 & 25 & 6.5 & 4.49 & 0.67 \\
\hline 22 & 0.5 & 0.2 & 0.30 & 0.20 & 5 & 10 & 50 & 6.5 & 5.13 & 0.77 \\
\hline 23 & 3.5 & 1.5 & 0.30 & 0.05 & 5 & 5 & 15 & 5.3 & 5.09 & 0.29 \\
\hline 24 & 0.5 & 1.5 & 0.10 & 0.05 & 10 & 15 & 15 & 6.5 & 7.00 & 0.52 \\
\hline 25 & 0.5 & 1.5 & 0.10 & 0.20 & 15 & 5 & 25 & 8.0 & 2.10 & 0.77 \\
\hline 26 & 3.5 & 1.0 & 0.10 & \begin{tabular}{|l|}
0.20 \\
\end{tabular} & 5 & 5 & 15 & 8.0 & 4.31 & 0.27 \\
\hline 27 & 2.0 & 1.0 & 0.30 & 0.05 & 10 & 5 & 50 & 5.3 & 2.68 & 1.01 \\
\hline
\end{tabular}

*D.W. : Dry weight 
Table 4. Analysis of variance of main effects of factors

\begin{tabular}{|l|r|r|r|r|}
\hline \multicolumn{1}{|c|}{ Factor } & \multicolumn{1}{|c|}{$\begin{array}{c}\text { Degree of } \\
\text { freedom }\end{array}$} & \multicolumn{1}{c|}{$\begin{array}{c}\text { Sum of } \\
\text { squares }\end{array}$} & \multicolumn{2}{c|}{$\begin{array}{c}\text { F* } \\
\text { value }\end{array}$} \\
\hline Peptone $(\mathrm{g} / \mathrm{L})$ & 1 & 13.26 & 11.36 & 19.25 \\
\hline$\left(\mathrm{NH}_{4}\right)_{2} \mathrm{SO}_{4}(\mathrm{~g} / \mathrm{L})$ & 1 & 0.38 & 0.32 & 0.53 \\
\hline Urea $(\mathrm{g} / \mathrm{L})$ & 1 & 3.52 & 2.69 & 4.55 \\
\hline $\mathrm{MgSO}_{4} .7 \mathrm{H}_{2} \mathrm{O}(\mathrm{g} / \mathrm{L})$ & 1 & 4.18 & 0.65 & 0.17 \\
\hline $\mathrm{KH}_{2} \mathrm{PO}_{4}(\mathrm{~g} / \mathrm{L})$ & 1 & 0.23 & 0.10 & 13.46 \\
\hline Locust bean gum $(\mathrm{g} / \mathrm{L})$ & 1 & 13.26 & 7.94 & 3.01 \\
\hline Volume $(\mathrm{mL})$ & 1 & 4.03 & 1.77 & 57.89 \\
\hline $\mathrm{pH}$ & 1 & 40.96 & 17.08 & \\
\hline
\end{tabular}

*F: Degree of freedom.

\section{DISCUSSION}

Most optimization process used for mannanase production deals with one factor at a time (Youssef et al., 2006) or using response surface methodology (Dan et al., 2012). However using Taguchi method enabled us to study eight different factors with three levels affecting mannanase production. According to the results produced, Taguchi method was found useful in mannnase production optimization as it increased production from 2.13 to $8.7 \mathrm{U} / \mathrm{mL}$ compared to other methods used. As a result, enzyme production was finally increased about $408 \%$, in relation to the initial step.

\section{REFERENCES}

Abe J, Hossain ZM, Hizukuri S (1994): Isolation of $\beta$ - mannanase producing microorganism. J.Ferment. Bioeng. 3: 259-261.

Akino T, Nakamura N, Horikoshi K (1987): Production of $\beta$-mannosidase and $\beta$-mannanase by an alkalophilic Bacillus sp. Appl Microbiol Biotechnol. 26: 323-237.

Arcand N, Kluepfel D, Paradis FW, Morosoli R, Shareck F (1993): $\beta$-Mannanase of Streptomyces lividans 66: cloning and DNA sequence of the manA gene and characterisation of the enzyme. Biochem J 290: 857-863.

Arisan-Atac I, Hodits $R$, Kristufek D, Kubicek CP (1993): Purification and characterization of a $\beta$-mannanase of Trichoderma reesei C-30m. Appl Microbiol Biotechnol 39: $58-62$.

Azin M, Moravej R, Zareh D. (2007): Production of xylanase by Trichoderma longibrachiatum on a mixture of wheat bran and wheat straw: Optimization of culture condition by Taguchi method. Enzyme and Microbial Techn. 40: 801805.

Bewley JD, Burton RA, Morohashi Y, Fincher GB (1997): Molecular cloning of a cDNA encoding a (1-4)- $\beta$-mannan endo-hydrolase from the seeds of germinated tomato (Lycopersicon esculentum). Planta 203: 454-459. 
Bhoria P, Singh G, Hoondal SG (2009): Optimization of mannanase production from Streptomyces sp. PG-08-03 in submerged fermentation. Bioresource 4(3): 11301138.

Dan Z, Wenxiang P, Gang S, Hongzhi L, Xue L, Jingping G (2012): Optimization of mannanase production by Bacillus sp. HDYM-05 through factorial method and response surface methodology. 6(1): 176-182.

de Vries RP and Visser J (2001): Aspergillus enzymes involved in degradation of plant cell wall polysaccharides. Microbiol Mol Biol Rev 65: 497-522.

Feng Y, He Z, Ong SL, Hu J, Zhang Z, Ng WJ (2003): Optimization of agitation, aeration, and temperature conditions for maximum $\beta$-mannanase production". Enzyme and Microbial Technology. 32: 282-289.

Ferreira HM. and Filho EXF. (2004): Purification and characterization of a $\beta$-mannanase from Trichoderma harzianum strain T4. Carbohydr polymers 57: 23-29.

Gübitz GM, Haltrich D, Latal B, Steiner W (1997): Mode of depolymerisation of hemicellulose by various mannanases and xylanases in relation to their ability of bleach softwood pulp. Appl Microbiol Biotechnol 47: 658-662

Jiang Z, Wei Y, Li D, Li L, Chai P, Kusakabe I (2006): High-level production, purification and characterization of a thermostable $\beta$-mannanase from the newly isolated Bacillus subtilis WY34" carbohydrate polymers. 66: 88-96.

Lee JT, Baiely CA, Cartwright AL (2003): A Guar meal germ and hull fractions differently affect growth performance and intestinal viscosity of broiler chickens. Poultry Sci 82: 1589- 1595.

Lowry OH, Rosebrough NJ, Farr AL, Randall RJ (1951): Protein measurement with the Folin phenol reagent. J Biol Chem 193: 267-275.

McCoy, $M$ (2001): Soaps and Detergents: An update on the latest developments within the detergent industry also introducing the latest new enzyme, a mannanase. Chem Eng News 20: 19-32.

Mendoza NS, Arai M, Sugimoto K, Ueda M, Kawaguchi T, Joson LM (1995): Cloning and sequencing of b-mannanase gene from Bacillus subtilis NM-39. Biochim Biophys Acta 1243: 552-554.

Montiel MD, Rodriguez J, Perel-Leblic MI, Hernandez M, Arias ME, Copa-Patino JL (1999): Screening of mannanases in actinomycetes and their potential application in the biobleaching of pine kraft pulps. Appl Microbiol Biotechnol 52: $240-245$.

Prasad KK, Mohan SV, Rao RS, Pati BR, Sarma PN (2005): Laccase production by Pleurotus ostreatusi 1804: Optimization of submerged culture conditions by Taguchi DOE methodology. Biochem Engineering J 24: 17-26.

Sachslehner A, Foidl G, Foidl N, Gübitz G, Haltrich D (2000): Hydrolysis of isolated coffee mannan and coffee extract by mannanases of Sclerotium rolfsii. J Biotechnol 80: 127-134.

Sachslehner A, Nidetzky B, Kulbe KD, Haltrich D (1998): Induction of mannanase, xylanase, and endoglucanase activities in Sclerotium rolfsii. Applied and Environmental Microbiology 64: 594-600. 
Schäfer T, Kirk O, Borchert TV, Fuglsang CC, Pedersen S, Salmon S, Olsen HS, Deinhammer $\boldsymbol{R}$, Lund $\boldsymbol{H}$ (2002): Enzymes for technical applications. In: Fahnestock SR, Steinbüchel SR (eds) Biopolymers, Wiley VCH, pp 377-437.

Somogyi M (1945): A new reagent for the determination of sugars. J Biol Chem 160: 61-68.

Stalbrand H, Saloheimo A, Vehmaanperà̀ J, Henrissat B, Penttila ̇̀M (1995): Cloning and expression in Saccharomyces cerevisiae of a Trichoderma reesei $\beta$ mannanase gene containing a cellulose binding domain. Appl Environ Microbiol 61: 1090-1097.

Stålbrand H, Siika-aho M, Viikari L (1993): Purification and characterization of two $\beta$ mannanases from Trichoderma reesei. J Biotechnol 29: 229-242.

Tamaru Y, Araki T, Amagoi H, Mori H, Morishita T (1995): Purification and characterisation of an extracellular $\beta 1,4$-mannanase from a marine bacterium, Vibrio sp. strain MA-138. Appl Environ Microbiol 61: 4454-4458.

Wong KKY and Saddler JN (1993): Applications of hemicelluloses in the food, feed and pulp and paper industries: In Coughlan MP, Hazlewood PG (eds) Hemicellulose and hemicellulases. Portland press, London, pp 127-143.

Wu G, Bryant MM, Voitle RA, Roland DA (2005): Effects of $\beta$-mannanase in corn-soy diets on commercial leghorns in second-cycle hens. Poultry Sci 84: 894-897.

Youssef AS, El-Naggar MY, El-Assar SA, Beltagy EA (2006): Optimization of cultural conditions for $\beta$-mannanase production by a local Aspergillus niger isolate. International J of Agric and Biotech., 4: 539-545.

\section{Bacillus دراسة الارجة المثلى للظروف البيئية وتركيباتها لإنتاج إنزيم المانانيز بواسطة بكتيرة velzensis NRC-1}

